\title{
PENERAPAN METODE SIMPLE ADDITIVE WEIGHTING DAN WEIGHTED PRODUCT DALAM PENENTUAN MERK TEPUNG TERIGU PADA RUMAH BAKERY
}

The Application Of The Simple Additive Weighting (SAW) Method and The Weighted (WP) Product Method In Determining The Brand Of Wheat Flour At Rumah Bakery

\author{
Winda Nuzlia ${ }^{1}$, Abdul Meizar ${ }^{2}$ \\ ${ }^{1}$ Jurusan Sistem Informasi, FTIK, Universitas Potensi Utama, Medan \\ ${ }^{2}$ Dosen Jurusan Sistem Informasi, FTIK, Universitas Potensi Utama, Medan \\ ${ }^{1,2}$ Universitas Potensi Utama, K.L. Yos Sudarso KM 6,5, No. 3A Tj. Mulia - Medan \\ E-mail: ${ }^{1}$ windanz199@gmail.com, ${ }^{2}$ abdulmeizar@gmail.com
}

\begin{abstract}
ABSTRAK
Rumah Bakery menjual berbagai macam jenis kue dan roti dengan kualitas yang sangat diutamakan bagi para pelanggannya. Dalam hal ini bahan utama adalah hal yang sangat mendukung cita rasa dan tekstur kue dan roti yang dijual. Banyaknya jenis pilihan merek tepung yang ada di pasaran saat ini dengan keunggulan dan karakteristik masing-masing merk yang ditawarkan, membuat Rumah Bakery lebih teliti dalam memilih merk tepung yang tepat. Diperlukan sebuah sistem yang dapat digunakan dalam memilih merk tepung sehingga dengan pertimbangan dan juga prioritas tertentu, agar dapat memilih merk tepung sesuai dengan kebutuhan pemilihan merk tepung. Salah satu metode yang digunakan dalam penelitian ini adalah metode Weighted Product (WP) dan Simple Additive Weighting (SAW). Penggunaan metode ini adalah agar memaksimalkan keputusan yang akan diambil berdasarkan beberapa kriteria dukungan seperti merk tepung terigu, tekstur tepung, penyerapan air dan bobot yang diberikan pada masing-masing kriteria, yang mana akan diketahui rangking alternatif untuk menentukan mana jenis merk tepung terbaik dengan menggabungkan kedua metode tersebut. Penelitian ini menghasilkan sebuah aplikasi sistem pendukung keputusan penentuan merk tepung terigu terbaik menggunakan Visual Basic 2010 dan Database yang digunakan adalah SQL Server 2008.
\end{abstract}

Kata Kunci : Merk Tepung Terigu, SAW, WP, Visual Basic 2010, SQL Server 2008

\section{ABSTRACT}

Rumah Bakery sells various types of cakes and breads with quality that are highly preferred for its customers. In this case, the main ingredients are things that really support the taste and texture of the cakes and breads being sold. The many types of choices of flour brands on the market today with the advantages and characteristics of each brand offered, make Rumah Bakery more careful in choosing the right flour brand. A system is needed that can be used in choosing a flour brand so that with certain considerations and priorities, you can choose a flour brand according to the needs of choosing a flour brand. One of the methods used in this study is the Weighted Product (WP) and Simple Additive Weighting (SAW) methods. The use of this method is to maximize the decisions that will be taken based on several supporting criteria such as the brand of flour, flour texture, water absorption and weight given to each criterion, which will determine the ranking of alternatives to determine which type of flour is the best brand by combining the two. the method. This research produces a decision support system application to determine the best wheat flour brand using Visual Basic 2010 and the database used is SQL Server 2008.

Keywords : Wheat Flour Brand, SAW, WP, Visual Basic 2010, SQL Server 2008 


\section{PENDAHULUAN}

Penelitian yang dilakukan oleh Abdul Meizar, 2018, dengan judul "Penentuan Kelayakan Calon Anggota Dewan Perwakilan Rakyat Partai Keadilan Sejahtera Dengan Menggunakan Metode Simple Additive Weighted Study Case: PKS Cabang Medan Belawan”. Adapun kesimpulan dari penelitian ini yaitu dengan penerapan metode SAW dapat memilih calong anggota DPR PKS Cabang Medan Belawan dengan cepat dan efisien. [1]

Penelitian yang dilakukan oleh Alfa Saleh, Ria dan Harris, 2017, "Metode Fuzzy Simple Additive Weighting (SAW) Dalam Menentukan Kualitas Kulit Ular Untuk Kerajinan Tangan (Studi Kasus: CV. Asia Exotica Medan)". Adapun kesimpulan dari penelitian ini yaitu dengan adanya metode Fuzzy dan SAW yang diterapkan untuk memaksimalkan keputusan yaitu kualitas yang akan diambil, adapun beberapa kriteria-kriteria yang telah ditentukan yaitu seperti ukuran kulit ular, fisik dan warna kulit ular dan bobot lalu menentukan normalisasi dari perhitungan kriteria untuk setiap kriteria tersebut juga diberikan setelah itu dengan nilai maximum lalu didapatkan hasil untuk menentukan perangkingan alternatif untuk menentukan jenis kulit ular yang terbaik. [2].

Penelitian yang dilakukan Lili Tanti, Linda Wahyuni, Tiffani dengan judul Sistem Pendukung Keputuan Penerimaan Permohonan Kredit Elektronik Berbasis Web Toko Metro Menggunakan FMADM Dengan Metode SAW. Memiliki kesimpulan, bahwa pemanfaatan metode dalam sistem pendukung keputusan sangat mempermudah pekerjaan dalam penentuan penerimaan kredit elektronik. [3].

Penelitian yang dilakukan Wiwi Verina, Yudhi Andrian, Iwan Fitrianto Rahmad yang berjudul Penerapan Metode Fuzzy SAW Untuk Penerimaan Pegawai Baru. Penelitian dilakukan dengan mencari nilai bobot untuk setiap kriteria, kemudian dilakukan proses perangkingan yang akan menentukan alternatif optimal yaitu menerima pegawai baru yang terbaik.[4].

Penelitian yang dilakukan Joko Riyanto, 2017, dengan judul "Perbandingan metode Weighted Product (WP) dan Simple Additive Weighting (SAW) Penilaian Kinerja Guru pada Madrasah Ibtidaiyah Negeri 3 Jakarta". Adapun kesimpulan dari penelitian ini yaitu penggabungan dua metode dipilih agar Kepala Sekolah diharapkan bisa mendapatkan dua alternatif pengolahan data untuk menunjang keputusan dalam penilain kinerja guru terbaik karena hasil perhitungan kedua metode ini tidak terlalu jauh dan lebih efisien karena waktu yang dibutuhkan dalam perhitungan lebih singkat.[5]

Penelitian dilakukan Avina Ulfa Aulia, Didi Supriyadi, Rima Dias Ramadhani yang berjudul Impelentasi Metode Simple Additive Weighting (SAW) dan Weighted Product (WP) Dalam Pemilihan Guru Teladan. Pada sistem pendukung keputusan ini menggunakan metode SAW, dimana dalam mencari penjumlahan terbobot dari suatu rating kinerja pada setiap alternatif yang terdapat pada semua atribut. Serta menggunakan metode WP, dimana metode ini menggunakan perkalian untuk menghubungkan rating atribut dengan bobot atribut yang bersangkutan [6].

Penelitian dilakukan Wayan Sriwidani, Ika Purwanti Ningrum, Rahmat Ramadhan. Konsep Sistem Pengambilan Keputusan (SPK) sangat berguna dalam dunia usaha dan bisnis sebagai sarana pengambilan keputusan dengan kelebihan dan kekurangannya masing-masing [7].

\section{METODE PENELITIAN}

Berikut adalah langkah - langkah yang diperlu dilakukan untuk mencapai tujuan perancangan yang dapat dilihat pada gambar 1 . 


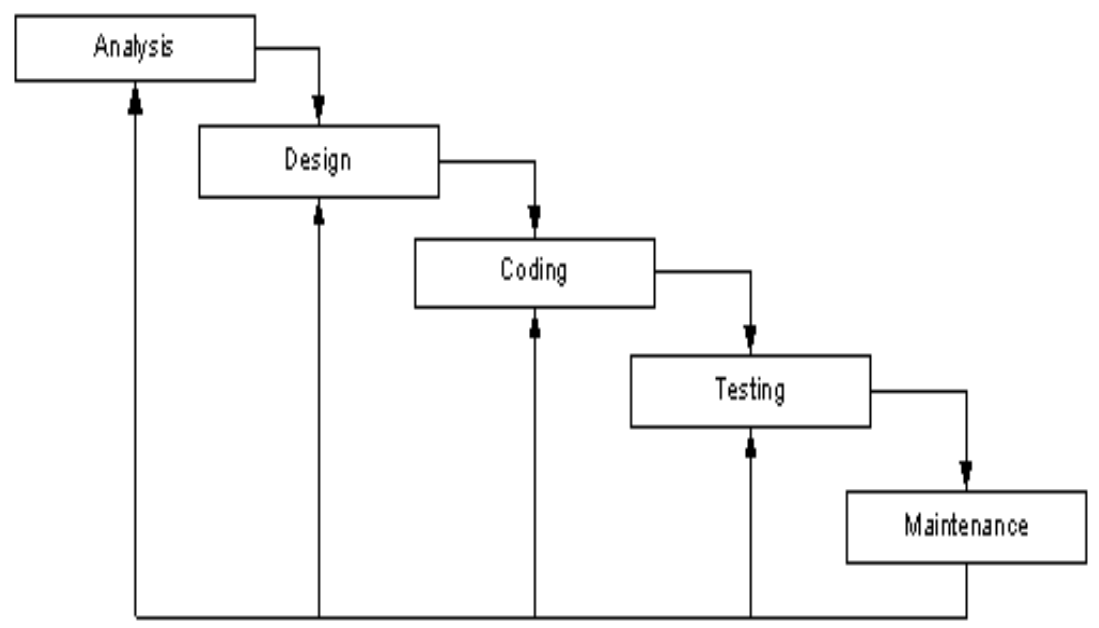

Gambar 1. Waterfall Metodologi Penelitian

Penjelasan tentang setiap tahapan dapat diringkas sebagai berikut :

1. Tahap Analisis (Analysis)

Adanya proses pengumpulan kebutuhan data secara lengkap untuk dianalisis dan didefinisikan. Kebutuhan seperti data mahasiswa dan data kriteria untuk program pada Rumah Bakery, sehingga dapat memudahkan penulis dalam memberikan solusi atau rancangan yang nantinya dapat memudahkan toko.

2. Tahap Desain (Design)

Setelah kebutuhan data analisi telah didapatkan maka proses selanjutnya yaitu tahan desain untuk membentuk karakteristik yang mudah dipahami oleh sistem perangkat lunak sebelum dimulai penulisan program. Desain yang dapat dilakukan pada tahap ini yaitu pemodelan desain yang akan dibuat dan proses aktivitas yang dilakukan pada sistem program yaitu UML yaitu Use Case Diagram, Class Diagram, Activity Diagram dan Sequence Diagram.

3. Tahap Pengkodean (Coding)

Pembuatan penentuan penerima siswa siswi magang dapat dilakukan setelah hasil tahap desain selesai. Pada tahap ini dilakukan pembuatan program secara bertahap yaitu menempatkan pengkodean perhitungan dua metode yaitu SAW dan WP pada program dengan penggunaan bahasa pemrograman seperti Visual Basic.Net dan Database SQL Server 2008.

4. Tahap Pengujian (Testing)

Pada tahapan ini program yang telah dirancang kemudian akan dilakukan tahap pengujian melalui pengujian Blackbox atau pengujian pada fungsi-fungsi eksternal sistem aplikasi diuji dan kemudian dievaluasi hasilnya. Selanjutnya akan dilakukan proses validasi apakah sistem penentuan merk tepung terigu ini dikatakan valid atau tidak yang hasilnya nanti akan menjadi hasil perangkingan.

5. Tahap Pemeliharaan (Maintenance)

Pada tahap pemeliharaan ini sistem perlu dilakukan untuk menjaga atau back-up semua datadata yang telah tersimpan dalam database aplikasi agar tidak hilang atau agar aplikasi tidak terinfeksi virus yang mengakibatkan gagalnya penerapan sistem aplikasi yang telah dirancang sebelumnya.

\section{HASIL DAN PEMBAHASAN}

\subsection{Penerapan Metode Simple Additive Weighting (SAW) dan Weighted Product (WP)}

Tahapan yang dilakukan untuk pemilihan tepung dengan metode Simple Additive Weighting(SAW) dan Weighted Product (WP)dapat dilihat pada struktur program flowchart sebagai langkah awal terlebih dahulu. Adapun flowchart metode Simple Additive Weighting (SAW) dan Weighted Product (WP) adalah sebagai berikut : 


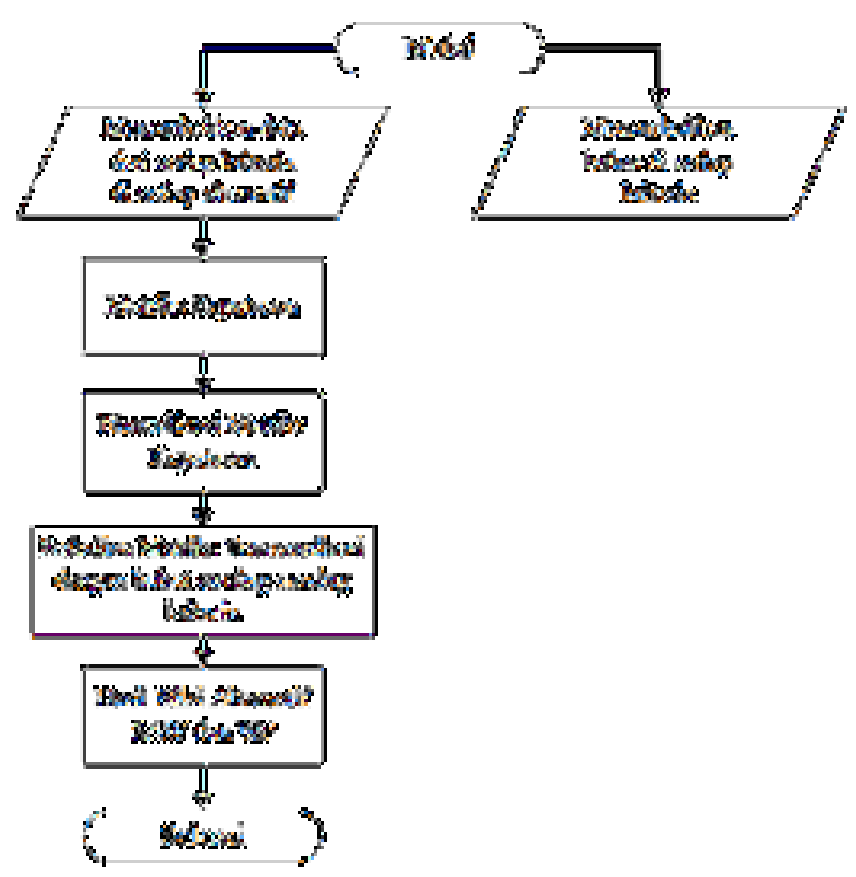

Gambar 2. Flowchart Metode SAW dan WP

\subsubsection{Studi Kasus}

1. Berikut ini kriteria yang digunakan untuk melakukan penilaian, yaitu:
a. Kadar abu
b. Kadar air
c. Daya serap air
d. Protein
e. Harga

2. Adapun penilaian bobot preferensi setiap kriteria, tabel ini menunjukkan kriteria beserta bobotnya dapat dilihat pada tabel 1 berikut.

Tabel 1. Preferensi Setiap Kriteria

\begin{tabular}{|c|l|c|c|}
\hline Kode Kriteria & Nama Kriteria & Nilai Bobot & Atribut \\
\hline C1 & Kadar Abu & 10 & Benefit \\
\hline C2 & Kadar Air & 15 & Benefit \\
\hline C3 & Daya Serap Air & 15 & Benefit \\
\hline C4 & Protein & 35 & Benefit \\
\hline C5 & Harga & 25 & Cost \\
\hline
\end{tabular}

3. Ada 5 (lima) merek tepung yang akan dijadikan (alternatif) untuk digunakan sebagai data bahan yang berkualitas, Adapun Alternatif yang dapat digunakan sebagai berikut :

A1 = Bogasari Cakra Kembar

A2 $=$ Bogasari Segitiga Biru

A3 = Hana Mas

A4 = Bogasari Kunci Biru

4. Penentuan tiap alternatif menggunakan semua atribut dengan penentuan range nilai yang disediakan yang menunjukan seberapa besar kepentingan antar kriteria. 
Tabel 2. Rating kecocokan dari setiap alternatif pada setiap kriteria

\begin{tabular}{|l|c|c|c|c|c|}
\hline \multirow{2}{*}{ Alternatif } & \multicolumn{5}{|c|}{ Kriteria } \\
\cline { 2 - 6 } & $\mathrm{C} 1(\%)$ & $\mathrm{C} 2(\%)$ & $\mathrm{C} 3(\%)$ & $\mathrm{C} 4(\%)$ & C5 (Rp) \\
\hline Bogosari Cakra Kembar & 0,64 & 14,3 & 60 & 13 & 12.000 \\
\hline Bogosari Segitiga Biru & 0,64 & 14 & 58 & 12 & 13.000 \\
\hline Hana Mas & 0,44 & 13,5 & 58 & 9 & 11.500 \\
\hline Bogasari Kunci Biru & 0,64 & 14 & 59 & 11 & 10.000 \\
\hline
\end{tabular}

\subsubsection{Perhitungan $S A W$}

1. Menentukan keputusan normalisasi matrik $X$ nilai terbobot.

$$
\begin{aligned}
& \mathrm{r}_{11}=0,64 / \mathrm{Max} \quad\{0,64 ; 0,64 ; 0,44 ; 0,64\}=0,64 / 0,64=1 \\
& \mathrm{r}_{21}=0,64 / \mathrm{Max} \quad\{0,64 ; 0,64 ; 0,44 ; 0,64\}=0,64 / 0,64=1 \\
& \mathrm{r}_{31}=0,44 / \mathrm{Max} \quad\{0,64 ; 0,64 ; 0,44 ; 0,64\}=0,64 / 0,64=0,688 \\
& \mathrm{r}_{41}=0,64 / \mathrm{Max} \quad\{0,64 ; 0,64 ; 0,44 ; 0,64\}=0,64 / 0,64=1 \\
& \mathrm{r}_{12}=14,3 / \operatorname{Max} \quad\{14,3 ; 14 ; 13,5 ; 14\}=14,3 / 14,3=1 \\
& \mathrm{r}_{22}=14 / \operatorname{Max} \quad\{14,3 ; 14 ; 13,5 ; 14\}=14 / 14,3 \quad=0,979 \\
& \mathrm{r}_{32}=13,5 / \mathrm{Max} \quad\{14,3 ; 14 ; 13,5 ; 14\}=13,5 / 14,3=0,944 \\
& \mathrm{r}_{42}=14 / \mathrm{Max} \quad\{14,3 ; 14 ; 13,5 ; 14\}=14 / 14,3 \quad=0,979 \\
& \mathrm{r}_{13}=60 / \mathrm{Max} \quad\{60 ; 58 ; 58 ; 59\}=60 / 60=1 \\
& \mathrm{r}_{23}=58 / \mathrm{Max} \quad\{60 ; 58 ; 58 ; 59\}=58 / 60=0,967 \\
& \mathrm{r}_{33}=58 / \mathrm{Max} \quad\{60 ; 58 ; 58 ; 59\}=58 / 60=0,967 \\
& \mathrm{r}_{43}=59 / \operatorname{Max} \quad\{60 ; 58 ; 58 ; 59\}=59 / 60=0,983 \\
& \mathrm{r}_{14}=13 / \operatorname{Max} \quad\{13 ; 12 ; 9 ; 11\}=13 / 13=1 \\
& \mathrm{r}_{24}=12 / \mathrm{Max} \quad\{13 ; 12 ; 9 ; 11\}=12 / 13=0,923 \\
& \mathrm{r}_{34}=9 / \mathrm{Max} \quad\{13 ; 12 ; 9 ; 11\}=9 / 13 \quad=0,692 \\
& \mathrm{r}_{44}=11 / \operatorname{Max} \quad\{13 ; 12 ; 9 ; 11\}=11 / 13 \quad=0,846 \\
& \mathrm{r}_{15}=\operatorname{Min}\{12.000 ; 13.000 ; 11.500 ; 10.000\} / 12.000=10.000 / 12.000=0,833 \\
& \mathrm{r}_{25}=\operatorname{Min}\{12.000 ; 13.000 ; 11.500 ; 10.000\} / 12.000=10.000 / 13.000=0,769 \\
& \mathrm{r}_{35}=\operatorname{Min}\{12.000 ; 13.000 ; 11.500 ; 10.000\} / 12.000=10.000 / 11.500=0,870 \\
& \mathrm{r}_{45}=\operatorname{Min}\{12.000 ; 13.000 ; 11.500 ; 10.000\} / 12.000=10.000 / 10.000=1
\end{aligned}
$$

Hasil Normalisasi :

\begin{tabular}{|rrrrr|}
\cline { 4 - 5 } 1 & 1 & 1 & 1 & 0,833 \\
1 & 0,979 & 0,967 & 0,923 & 0,769 \\
0,688 & 0,944 & 0,967 & 0,692 & 0,870 \\
1 & 0,979 & 0,983 & 0,846 & 1 \\
\hline
\end{tabular}

2. Proses per-rangking-an dengan menggunakan bobot yang telah diberikan oleh pengambil

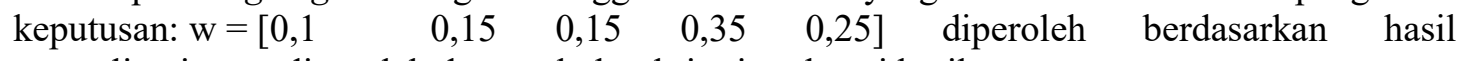
normalisasi yang diperoleh dengan bobot kriteria sebagai berikut.

$$
\begin{array}{ll}
V_{1}=(1)(0,1)+(1)(0,15)+(1)(0,15)+(1)(0,35)+(0,833)(0,25) & =0,958 \\
V_{2}=(1)(0,1)+(0,979)(0,15)+(0,967)(0,15)+(0,923)(0,35)+(0,769)(0,25) & =0,907 \\
V_{3}=(0,688)(0,1)+(0,944)(0,15)+(0,967)(0,15)+(0,962)(0,35)+(0,870)(0,25) & =0,815 \\
V_{4}=(1)(0,1)+(0,979)(0,15)+(0,983)(0,15)+(1)(0,846)+(1)(0,25) & =0,941
\end{array}
$$

3. Penentuan alternatif menunjukkan nilai terbesar dan akan di pilih sebagai alternatif terbaik. Dengan kata lain akan terpilih sebagai bahan tepung yang berkualitas. Tabel 3 akan 
menunjukkan rangkingakhir yang diperoleh dengan menggunakan metode Simple Additive Weighting (SAW).

Tabel 3. Hasil pe-rangking-an dengan metode Simple Additive Weighting (SAW)

\begin{tabular}{|c|c|c|c|}
\hline Kode & MerekTepung & Nilai SAW & Rangking \\
\hline A1 & Bogasari Cakra Kembar & 0,958 & 1 \\
\hline A4 & Bogasari Kunci Biru & 0,907 & 2 \\
\hline A2 & Bogasari Segitiga Biru & 0,815 & 3 \\
\hline A3 & Hana Mas & 0,947 & 4 \\
\hline
\end{tabular}

Hasil yang di tujukkan pada tabel 3 adalah menunjukkan bahwa nilai hasil tertinggi pada tepung terigu yaitu Tepung Terigu Merek Bogasari Cakra Kembar dengan Metode Simple Additive Weighting nilai = 0, 958 dan dengan Rangking 1 (pertama)

\subsubsection{Perhitungan $W P$}

1. Dilakukan proses normalisasi $(S)$ matrik keputusan dengan cara mengalikan ranking atribut, dimana ranking atribut terlebih dahulu harus di pangkatkan dengan bobot atribut.

$$
\begin{aligned}
& S_{I}=\left(0,64^{0,10}\right) *\left(14,3^{0,15}\right) *\left(60^{0,15}\right) *\left(13^{0,35}\right) *\left(12.000^{-0,25}\right)=0,620 \\
& S_{2}=\left(0,64^{0,10}\right) *\left(14^{0,15}\right) *\left(58^{0,15}\right) *\left(12^{0,35}\right) *\left(13.000^{-0,25}\right)=0,586 \\
& S_{3}=\left(0,44^{0,10}\right) *\left(13,5^{0,15}\right) *\left(58^{0,15}\right) *\left(9^{0,35}\right) *\left(11.500^{-0,25}\right)=524 \\
& S_{4}=\left(0,64^{0,10}\right) *\left(14^{0,15}\right) *\left(59^{0,15}\right) *\left(11^{0,35}\right) *\left(10.000^{-0,25}\right)=0,606
\end{aligned}
$$

2. Proses preferensi untuk tiap alternatif $(\mathrm{V})$.

$$
\begin{array}{ll}
\mathrm{V}_{1} & =\frac{0,620}{0,620+0,586+0,524+0,606} \\
& =0,265 \\
\mathrm{~V}_{2} & =0 \frac{0,586}{0,620+0,586+0,524+0,606} \\
\mathrm{~V}_{3} & =0,251 \\
\mathrm{~V}_{4} & =0,224 \\
& =0,259
\end{array}
$$

3. Penentuan alternatif menunjukkan nilai terbesar dan akan di pilih sebagai alternatif terbaik. Dengan kata lain akan terpilih sebagai bahan tepung yang berkualitas. Tabel 4 akan menunjukkan rangking akhir yang diperoleh dengan menggunakan metode Weighted Product (WP).

Tabel 4. Hasil pe-rangking-an dengan metode Weighted Product(WP)

\begin{tabular}{|c|c|c|c|c|}
\hline Kode & Merek Tepung & Nilai S & Nilai $V$ & Rangking \\
\hline A1 & Bogasari Cakra Kembar & 0,620 & 0,265 & 1 \\
\hline A4 & Bogasari Kunci Biru & 0,606 & 0,259 & 2 \\
\hline A2 & Bogasari Segitiga Biru & 0,586 & 0,251 & 3 \\
\hline A3 & Hana Mas & 0,524 & 0,224 & 4 \\
\hline
\end{tabular}

Hasil yang ditujukkan pada tabel 4 adalah menunjukkan bahwa nilai hasil tertinggi pada tepung terigu yaitu Merek Bogasari Cakra Kembar dengan Metode Weighted Product nilai = 0,255 dengan Rangking 1 (pertama). 


\subsubsection{Use Case Diagram}

Use Case Diagram menunjukkan beberapa tahap aktivitas-aktivitas atau cases yang akan dilakukan oleh seorang aktor pengguna sistem yang dibuat. Berikut adalah Use Case Diagram pada penelitian ini :

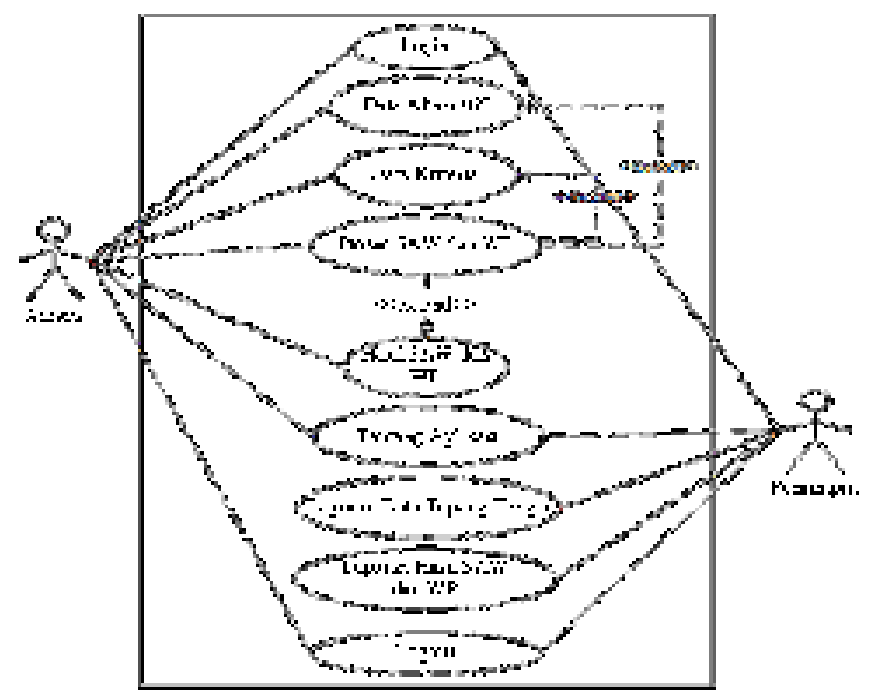

Gambar 3. Use Case Diagram

Keterangan dari Usecase Diagram tersebut adalah sebagai berikut :

1. Admin dan Pemimpin yang memiliki akses login ke sistem agar bisa masuk dan menggunakan sistem.

2. Admin dan pemimpin dapat melihat informasi tentang aplikasi yang digunakan.

3. Selanjutnya admin mendata alternatif atau merk tepung terigu secara lengkap.

4. Setelah itu, admin mendata kriteria secara lengkap.

5. Kemudian, admin dapat melakukan proses perhitungan penentuan merk tepung terigu dengan metode SAW dan WP.

6. Kemudian, sistem akan menampilkan hasil perhitungan SAW dan WP serta menampilkan rangking merk tepung terigu secara berurut dengan nilai $\mathrm{V}$ masing-masing.

7. Saat pemimpin pada sistem, pemimpin dapat melihat data tepung terigu dam hasil analisa perhitungan SAW dan WP yang dilakukan oleh admin berupa laporan.

8. Admin dan Pemimpin dapat melakukan Logout setelah menggunakan aplikasi tersebut.

\subsubsection{Class Diagram}

Rancangan kelas-kelas yang akan dibuat untuk merancang sistem dapat dilihat pada gambar 4. berikut : 


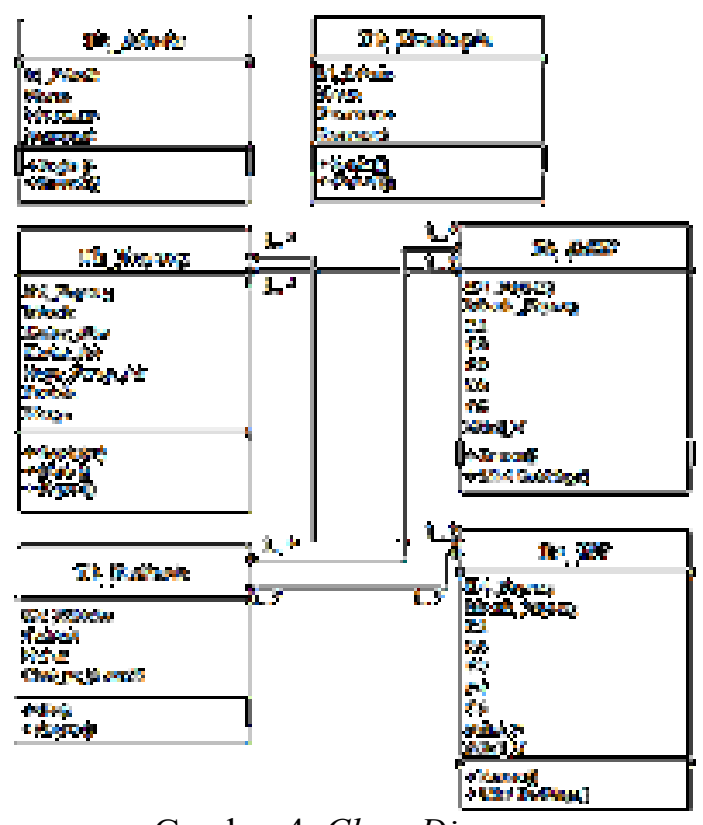

3.2. Implementasi Sistem

Gambar 4. Class Diagram

1. Tampilan Form Data Kriteria

Halaman ini adalah halaman untuk menampilkan tabel data kriteria. Tampilan Form Data kriteri dari aplikasi yang telah dibuat dapat dilihat pada gambar 5.

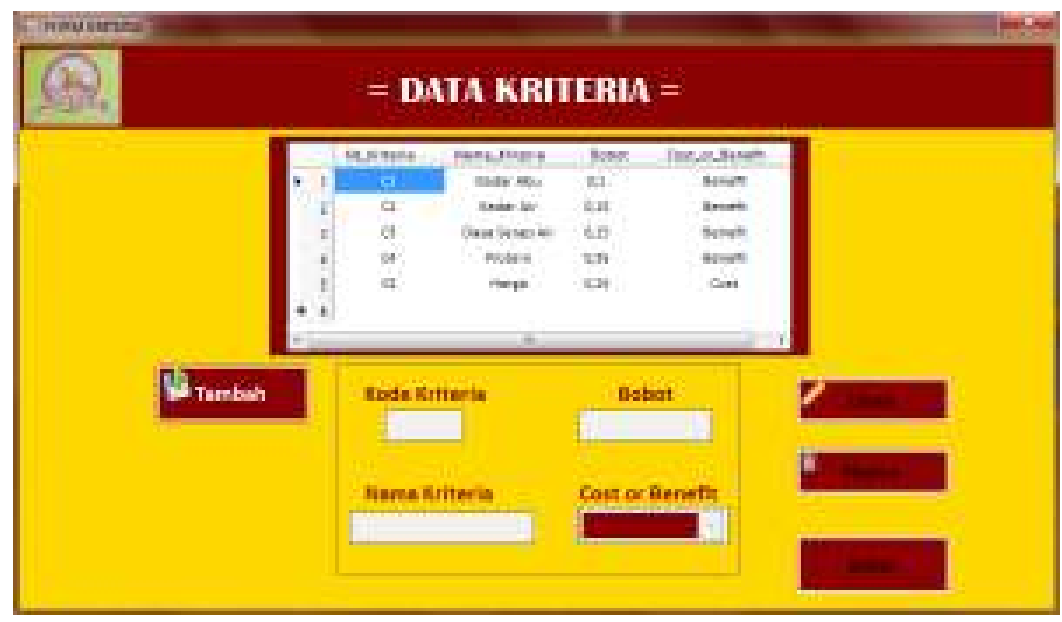

Gambar 5. Form Data Kriteria

2. Tampilan Form Data Alternatif

Halaman ini adalah halaman untuk menampilkan alternatif berdasarkan nomor pengujian produksi alternatif. Tampilan Form Data Alternatif dari aplikasi yang telah dibuat dapat dilihat pada gambar 6 . 


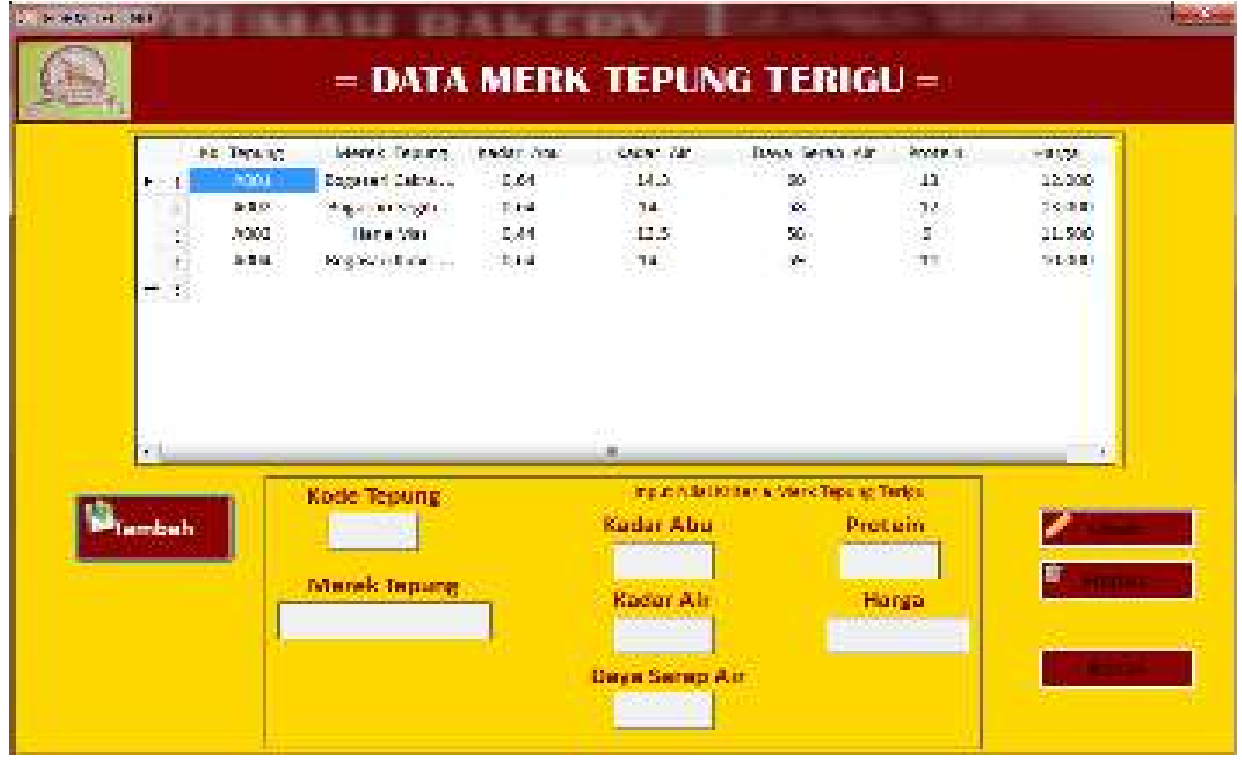

Gambar 6. Form Data Alternatif

3. Tampilan Form Hasil Analisa Perhitungan SAW dan WP

Halaman ini adalah halaman untuk menampilkan hasil perhitungan kedua metode SAW dan WP. Tampilan Form Hasil Analisa Perhitungan SAW dan WP dari aplikasi yang telah dibuat dapat dilihat pada gambar 7 .

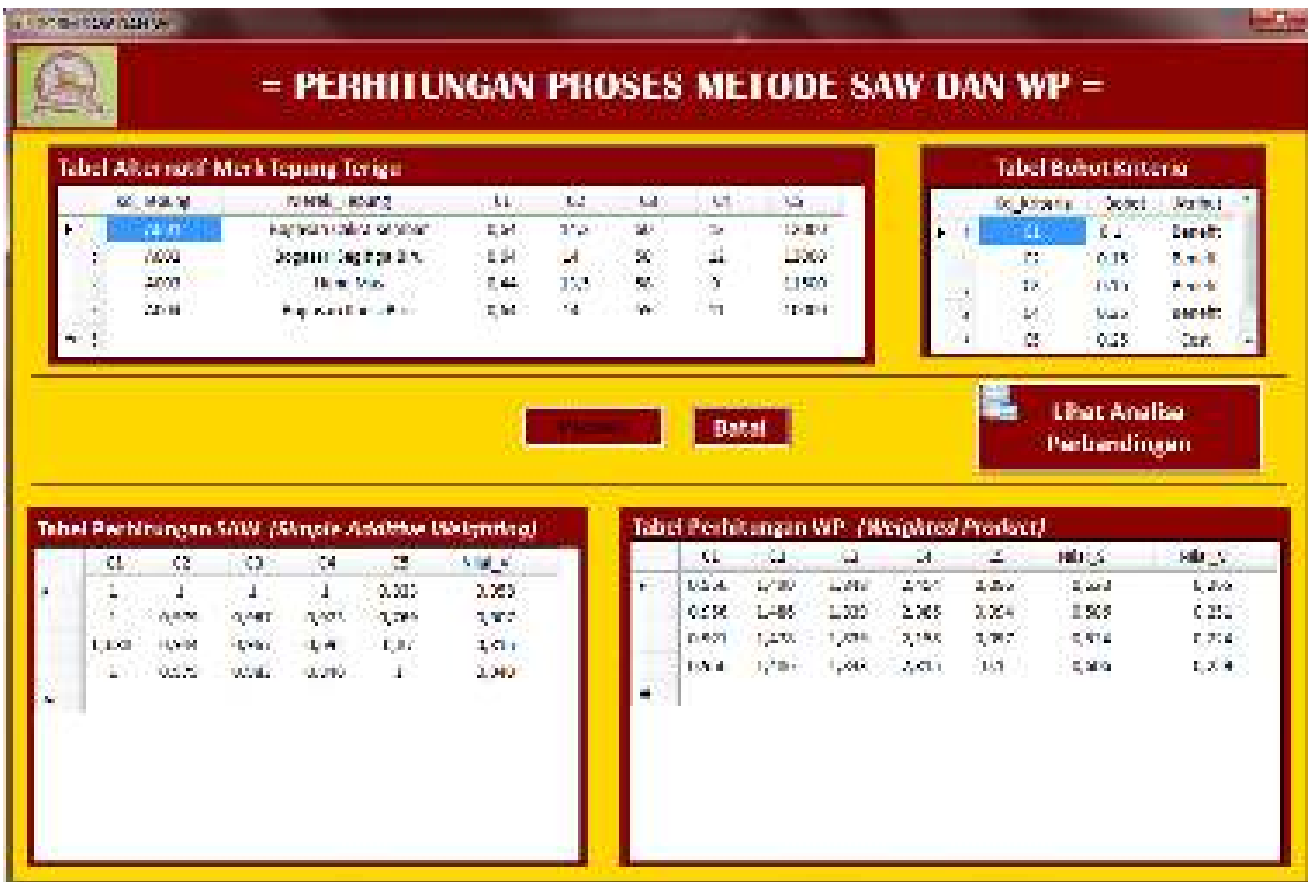

Gambar 7. Form Hasil Analisa Perhitungan SAW dan WP

4. Tampilan Form Hasil Perbandingan SAW dan WP

Halaman ini adalah halaman untuk menampilkan hasil perbandingan kedua metode SAW dan WP. Tampilan Form Hasil Perbandingan SAW dan WP dari aplikasi yang telah dibuat dapat dilihat pada gambar 8 . 


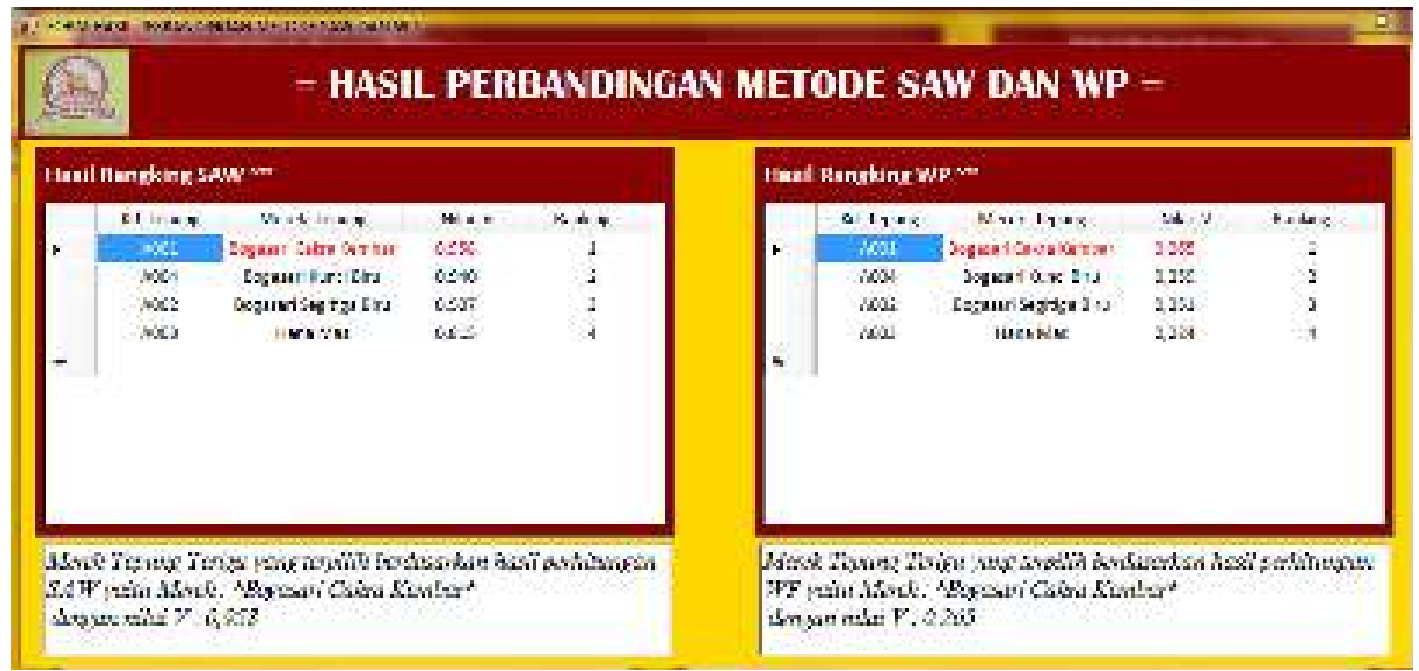

Gambar 7. Form Hasil Perbandingan SAW dan WP

\section{KESIMPULAN} dilakukan :

Berikut adalah kesimpulan yang berdasarkan hasil pembahasan dan uji coba yang telah

1. Penerapan sistem pendukung keputuan dalam Penentuan Merk Tepung Terigu pada Rumah Bakery dapat mempermudah pihak toko dalam merekomendasikan merk tepung terigu yang akan digunakan.

2. Sistem aplikasi ini mampu menampilkan sistem informasi untuk penilaian setiap alternatif dengan bobot kriteria seperti Kadar Abu, Kadar Air, Daya Serap Air, Protein, Harga untuk proses pemilihan merk tepung terigu.

3. Hasil keputusan akhir dari sistem dengan pemanfaatan metode SAW dan WP adalah berupa rangking data alternatif atau merk tepung terigu yang telah sesuai dengan perhitungan bobot kriteria

\section{SARAN}

Untuk menyempurnakan aplikasi ini maka peneliti sangat memperhatikan beberapa saran atau tambahan agar dapat mengembangkan sistem aplikasi yang dijalankan sebagai berikut:

1. Lebih teliti dalam halnya menambahkan data-data yang disimpan pada database sebagian tidak merusak perhitungan metode pada sistem.

2. Desain interface dan fitur aplikasi yang dibangun masih sederhana. Sehingga diharapkan pengembangan sistem yang lebih menarik dan interaktif untuk memudahkan pihak perusahaan dalam penggunanan aplikasi.

3. Selalu mem-backup data agar terhindar dari kemungkinan terjadinya kehilangan data penting yang disebabkan oleh kerusakan atau error system pada perangkat keras.

\section{UCAPAN TERIMA KASIH}

Penulis mengucapkan terima kasih kepada pihak Universitas Potensi Utama yang telah membantu dalam menyelesaikan laporan penelitian ini dengan baik. 


\section{DAFTAR PUSTAKA}

[1] Kom, A. M. M. (2017, November). PENENTUAN KELAYAKAN CALON ANGGOTA DEWAN PERWAKILAN RAKYAT PARTAI KEADILAN SEJAHTERA DENGAN MENGGUNAKAN METODE SIMPLE ADDITIVE WEIGHTED (STUDY CASE: PKS CABANG MEDAN BELAWAN). In Seminar Nasional Informatika (SNIf) (Vol. 1, No. 1, pp. 61-67).

[2] Saleh, A., Sari, R. E., \& Kurniawan, H. (2017, October). Metode Fuzzy Simple Additive Weighting (Saw) Dalam Menentukan Kualitas Kulit Ular Untuk Kerajinan Tangan (Studi Kasus: Cv. Asia Exotica Medan). In Seminar Nasional Informatika (SNIf) (Vol. 1, No. 1, pp. 18-23).

[3] Tanti, L., Linda Wahyuni, T., \& Utama, S. P. SISTEM PENDUKUNG KEPUTUSAN PENERIMAAN PERMOHONAN KREDIT ELEKTRONIK BERBASIS WEB PADA TOKO METRO MENGGUNAKAN FMADM DENGAN METODE SAW.

[4] Verina, W., Andrian, Y., \& Rahmad, I. F. (2015). Penerapan Metode Fuzzy SAW Untuk Penerimaan Pegawai Baru (Studi Kasus: STMIK Potensi Utama). Sisfotenika, 5(1), 60-70.

[5] Riyanto, J. (2017). Perbandingan metode weighted product (wp) dan simple additive weighting (saw) penilaian kinerja guru pada madrasah ibtidaiyah negeri 3 jakarta. Jurnal Informatika Universitas Pamulang, 2(4), 179-183.

[6] Aulia, A. U., Supriyadi, D., \& Ramadhani, R. D. (2018). IMPLEMENTASI METODE SIMPLE ADDITIVE WEIGHTING (SAW) DAN WEIGHTED PRODUCT (WP) DALAM PEMILIHAN GURU TELADAN (STUDI K).

[7] Sriwidani, W., Ningrum, I. P., \& Ramadhan, R. (2016). SISTEM PENDUKUNG KEPUTUSAN PENERIMAAN KARYAWAN PADA PT. SULTRA INTI RODA PERKASA MENGGUNAKAN METODE WEIGHTED PRODUCT (WP) DAN SIMPLE ADDITIVE WEIGHTING (SAW). semanTIK, 2(1). 